Discussion Paper No. 09-021

How Clean is Clean?

Incremental Versus Radical Technological Change in Coal-Fired Power Plants

Klaus Rennings, Peter Markewitz, and Stefan Vögele

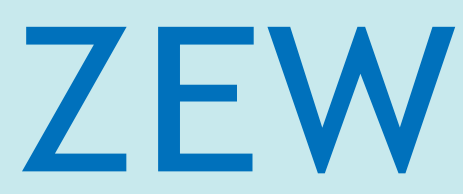

Zentrum für Europäische Wirtschaftsforschung $\mathrm{GmbH}$ Centre for European Economic Research 
Discussion Paper No. 09-021

\title{
How Clean is Clean? \\ Incremental Versus Radical Technological Change in Coal-Fired Power Plants
}

\author{
Klaus Rennings, Peter Markewitz, \\ and Stefan Vögele
}

Download this ZEW Discussion Paper from our ftp server:

ftp://ftp.zew.de/pub/zew-docs/dp/dp09021.pdf

Die Discussion Papers dienen einer möglichst schnellen Verbreitung von neueren Forschungsarbeiten des ZEW. Die Beiträge liegen in alleiniger Verantwortung der Autoren und stellen nicht notwendigerweise die Meinung des ZEW dar.

Discussion Papers are intended to make results of ZEW research promptly available to other economists in order to encourage discussion and suggestions for revisions. The authors are solely responsible for the contents which do not necessarily represent the opinion of the ZEW. 


\section{Das Wichtigste in Kürze}

In der Diskussion um Innovationen für eine nachhaltige Entwicklung werden häufig radikale Innovationen gefordert, damit die Transformation der Gesellschaft hin zu einem nachhaltigen Energiesystem gelingen kann. Begründet wird dies mit einer höheren Umwelteffizienz dieser Innovationen. Empirische Evidenz für diese Hypothese ist allerdings kaum zu finden.

Dieses Papier prüft vor dem Hintergrund eines weltweit zunehmenden Einsatzes von Kohlekraftwerken und der dadurch zu erwarteten Umweltbelastungen die Hypothese, dass radikale Innovationen im Vergleich zu inkrementellen Innovationen überlegen sind. Anhand von Beispielen fossil befeuerter Kraftwerke wird untersucht, welche Hemmnisse radikalen Innovationen grundsätzlich entgegenstanden. Die Analyse zeigt, dass sich seit den 70er Jahren in Deutschland keine radikale Innovation mehr im Kraftwerksbereich durchsetzten konnte. Als Fallstudie werden die Druckkohlenstaubfeuerung (radikale Innovation) und überkritische Kohlekraftwerke (inkrementelle Innovation) miteinander verglichen. Die Fallstudie veranschaulicht die ausgeprägte Pfadabhängigkeit im Kraftwerksbereich.

Hieraus lassen sich auch Hinweise für zukünftige Forschungs- und Entwicklungsarbeiten ableiten. Das Risiko, dass neue Techniklinien sich nicht etablieren, ist besonders groß, wenn es sich um die Entwicklung neuer Komponenten oder eine Trendumkehr auf Komponentenebene handelt, die letztendlich eine radikale Innovation des Kraftwerkssystems bedeuten. Die Wahrscheinlichkeit, dass sich eine Neuentwicklung durchsetzt, ist auf dem Gebiet der fossilen Kraftwerkstechnik umso größer, je näher sie sich an den etablierten Techniklinien orientiert. Die Zukunftspotenziale für radikale Innovationen auf dem Gebiet der Kraftwerkstechnik sind insbesondere aufgrund des relativ hohen Kostendrucks, der geringen Risikobereitschaft von Energieversorgungsunternehmen und der großen zeitlichen Dynamik des inkrementellen Fortschritts bei konventionellen Referenztechnologien als relativ gering anzusehen. Für zukünftige F\&E-Arbeiten auf dem großtechnischen Kraftwerkssektor lässt sich folgern, dass die Wahrscheinlichkeit eines Erfolgs einer Neuentwicklung umso größer ist, je näher sie sich an den etablierten Techniklinien orientiert. Auch im Zuge der Energiemarktliberalisierung sind für diesen Technikbereich kaum radikale Neuerungen zu erwarten.

Die Erkenntnisse lassen sich auch für die Bewertung von Risiken bzw. Erfolgswahrscheinlichkeiten derzeit in der Entwicklung befindlicher Techniken nutzen. Dies wird am Beispiel heute favorisierter Techniklinien für die $\mathrm{CO}_{2}$-Abscheidung diskutiert.

Auch was die Umweltfreundlichkeit von Kraftwerken angeht, so zeigt dieses Papier, muss nicht immer die radikale Lösung angestrebt werden. Kleine, inkrementelle Schritte können ökologisch vorteilhaft und ökonomisch leichter zu realisieren sein. 


\section{Non-technical summary}

In the discussion on innovations for sustainable development, radical innovations are often seen as necessary to establish eco-efficient technological systems. It is assumed that only a regime shift from the existing (unsustainable) technological system to a more sustainable one can solve the ecological problems. In this perspective radical innovations are needed for a successful transition to a system perceived as sustainable.

The justification for radical change is the greater environmental efficiency of these innovations. This hypothesis is, however, not supported by empirical evidence. Against the background of a globally increasing use of coal-burning power plants and the environmental impacts to be expected, the hypothesis that radical innovations are superior to incremental innovations is reflected in this paper.

We examine the diffusion of radical innovations in the field of power plants and the basic obstacles these innovations were confronted with. As an example for the ex-post-analysis we select the case of pressurised pulverised coal combustion as a radical innovation and supercritical coal-fired power plants as an incremental innovation. The analysis shows that pressurised pulverised coal combustion did not fulfil the expectations. Although an improved economic and ecological performance of the radical innovation was expected ex ante, unforeseen innovations were developed for the old technology (supercritical coal-fired power plants). Thus the radical innovation failed.

It can be concluded that the dynamics of technical progress and the development of incremental innovations should not be underestimated. Assumed advantages for radical technologies should be verified, and the technology assessment should be regularly updated regarding cost and efficiency advantages.

In general the future potential of radical innovations in the field of power plant technology is to be regarded as relatively low, especially due to comparatively high cost-pressure, the reluctance of energy supply companies to take risks and the dynamics of technological progress facilitating incremental innovations on the basis of conventional reference technology. The conclusion for future research and development (R\&D) work in the sector of large-scale power plants is that an innovation is more likely to succeed the more it is geared to established technological trajectories. In the context of energy market liberalisation, hardly any radical innovations are expected in this field of technology. The findings of this paper may also be helpful in evaluating risks or probabilities of success of technologies being developed. As an example technological trajectories currently favoured in $\mathrm{CO}_{2}$ capture are discussed. 


\title{
How clean is clean? Incremental versus radical tech- nological change in coal-fired power plants
}

\author{
Klaus Rennings ${ }^{1}$, Centre for European Economic Research (ZEW), Mannheim
}

Peter Markewitz, Stefan Vögele, Forschungszentrum Jülich, Institute of Energy Research Systems Analysis and Technology Evaluation (IEF-STE)

\begin{abstract}
In the discussion on innovations for sustainable development, radical innovations are frequently called for in order that the transformation of society to a system perceived as sustainable can succeed. The reason given for this is the greater environmental efficiency of these innovations. This hypothesis is, however, not supported by empirical evidence.

Against the background of a globally increasing use of coal-burning power plants and the environmental impacts to be expected, the hypothesis that radical innovations are superior to incremental innovations is reviewed on the basis of fossil fuel power plants. This paper examines the diffusion of incremental and radical innovations in the field of power plants and the basic obstacles with which these innovations were confronted. To give an example, Pressurised Pulverised Coal Combustion (PPCC) as a radical innovation and supercritical coal-fired power plants as an incremental innovation are compared.

An ex-post analysis of the German R\&D portfolio in the past three decades in the field of power plants environmentally shows that technologies which were radical innovations had great difficulties in becoming accepted by possible investors. The future potential of radical innovations in the field of power plant technology is to be regarded as relatively low, especially due to comparatively high cost-pressure, the reluctance of utilities to take risks and the temporal dynamics of technological progress facilitating incremental innovations on the basis of conventional reference technology.

The conclusion for future R\&D work in the sector of large-scale power plants is that an innovation is more likely to succeed the more it follows established technological trajectories. In the context of energy market liberalisation, hardly any radical innovations are expected in this field of technology. The findings of this paper may also be helpful in evaluating risks or probabilities of success of technologies being developed. As an example technological trajectories currently favoured in $\mathrm{CO}_{2}$ capture are discussed.
\end{abstract}

Keywords: Radical innovations, incremental innovations, carbon capture storage, coal power plants

JEL Signature: Q01, Q55, O31, O33

\footnotetext{
${ }^{1}$ Corresponding author: Klaus Rennings, ZEW, P.O. Box 103443, D-68161 Mannheim, E-mail: rennings@zew.de
} 


\section{Introduction}

In the discussion on innovations for sustainable development, radical innovations are frequently called for in order that the transformation of society to a system perceived as sustainable can succeed (Vellinga 2004). The reason given for this is the expectation that these innovations will increase environmental efficiency by a factor of 10, compared to a factor of 2 for incremental innovations (Geels, et al. 2004).

The literature, however, provides hardly any empirical evidence in favour of this hypothesis. Supporters of this view admit that such changes need at least one generation in order to become accepted, since they have to pass through several stages. Radical innovations should ideally develop first in small market niches, then diffuse and finally replace existing technologies. In the literature this idea of innovation is described as Transition Management (Geels 2004).

Against the backdrop of an increasing use of coal-fired power plants and the environmental burden to be expected, the potential and the relevance of radical innovations in this field is of interest to researchers. The International Energy Agency IEA assumes that global electricity and capacity need will increase significantly in the next decade and that fossil fuel power plants will be the central basis of future electricity generation worldwide. (IEA 2008b)

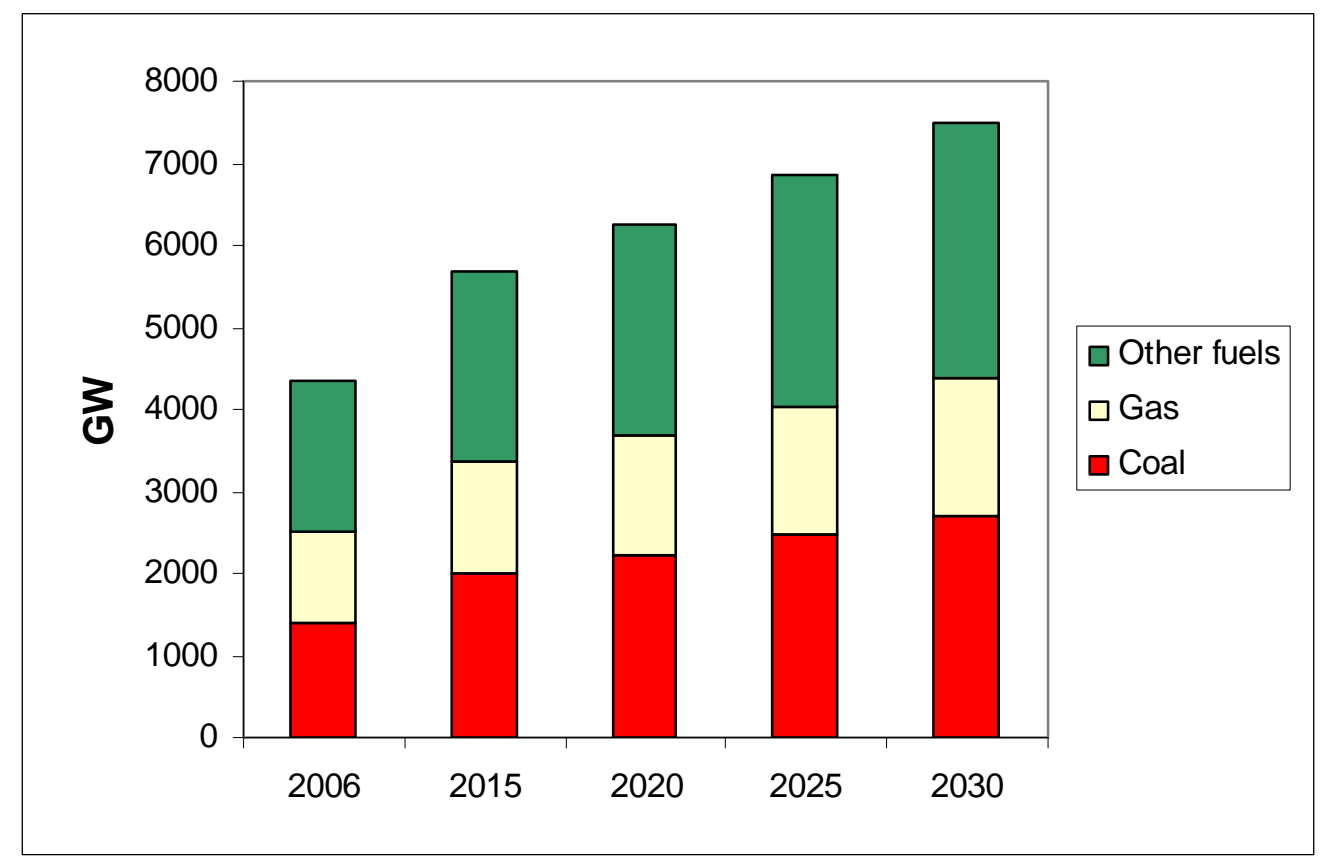

Figure 1: Predicted increase in capacity worldwide (IEA 2008b)

The development of power plant technology in Germany is used as an example in this study 
to show in an ex-post analysis, to what extent radical innovations have been successful and what were the obstacles with which they were confronted. The relevance of these aspects for future $R \& D$ policy is shown by applying the concept to the ongoing discussion of $\mathrm{CO}_{2}$ capture.

Firstly, the concepts of radical and incremental innovation are described on the basis of theories on innovation in evolutionary economics. Section 3 analyses the development of the R\&D portfolio in the last decades. The paper uses the examples of Pressurised Pulverised Coal Combustion and supercritical coal-fired power plants in order to compare the development of radical and incremental innovations. This part is followed by an evaluation of risks and probabilities of success with regard to technological trajectories of $\mathrm{CO}_{2}$ capture which are at present globally favoured. Section 5 draws some conclusions.

\section{Incremental and radical innovations from the perspec- tive of evolutionary economics}

In accordance with the OECD Guidelines for Collecting and Interpreting Technological Innovation Data (OECD 2005), we distinguish between technical and organisational innovations. Technical innovations are divided into product and process innovations:

- Process innovations occur when a given amount of output (goods, services) can be produced with less input.

- Product innovations require improvements to existing goods (or services) or the development of new goods. Product innovations in machinery in one firm are often process innovations in another firm.

- Organisational innovations include new forms of management, e.g. total quality management.

The following definition of environmental innovation is used in this report (Kemp and Arundel 1998, Rennings and Zwick 2002): Environmental innovations consist of new or modified processes, techniques, practices, systems and products to avoid or reduce environmental harms. Environmental innovations may be developed with or without the explicit aim of reducing environmental harm. They also may be motivated by the usual business goals such as profitability or enhancing product quality. Many environmental innovations combine an environmental benefit with a benefit for the firm or user.

This means that, among all innovations, environmental innovations are technological, economic, institutional and/or social changes which result in an improvement in environmental 
quality (Klemmer, et al. 1999). Regarding improvements of coal-fired power plants, it may be controversial if they can be characterized as environmental innovations. However, if the greenhouse gas emissions decrease significantly, or energy efficiency is improved, they can be seen as an environmental innovation.

The extent to which an improvement is made may be classified according to their degree of “novelty”. (Freemann 1992) states that incremental innovations are continuous improvements of existing technological systems (for instance, the optimisation of an exhaust air filter), whereas radical innovations are discontinuous processes (for instance, the introduction of fuel cells).

Before discussing the development of incremental and radical innovations in detail, these concepts must be defined (Garcia and Calantone 2002). The terms of radical or incremental innovations may be used to refer to a technology at the component level as well as to the entire technological process. Figure 2 shows the different levels of analysis.

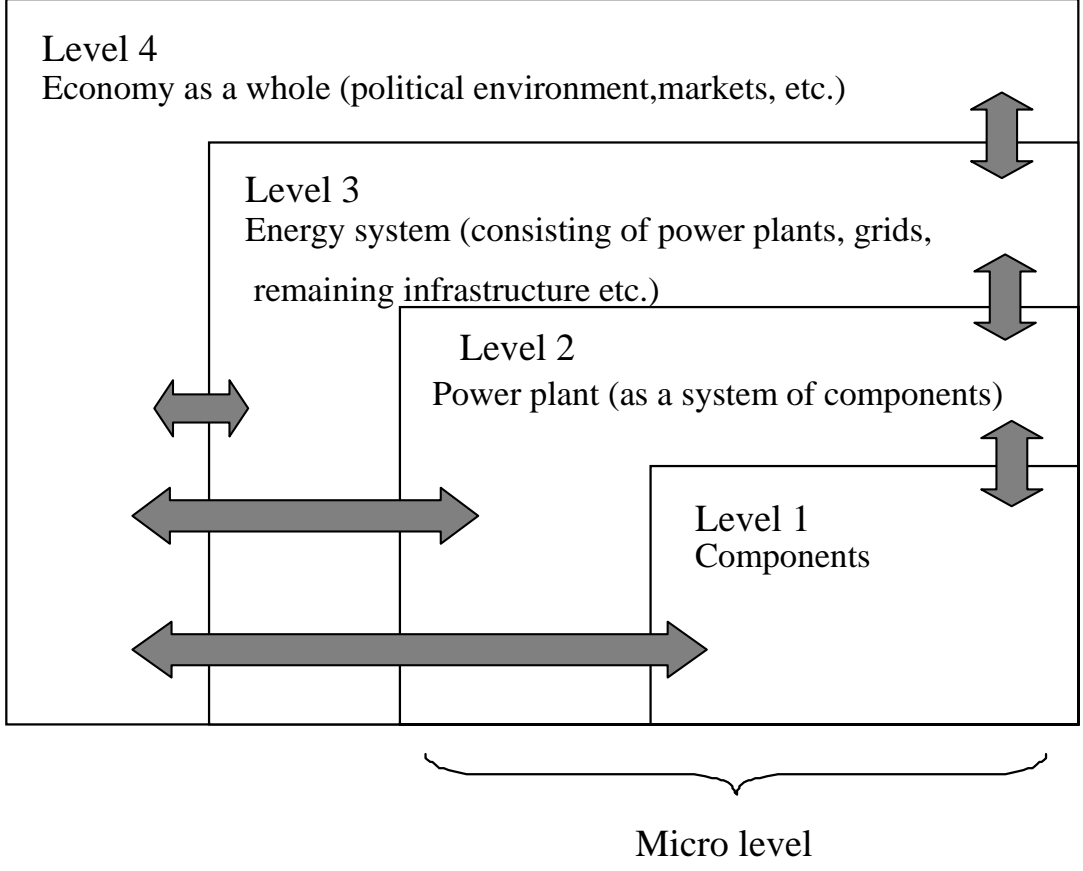

Figure 2: Levels of ex-post analysis

As will be demonstrated below, a radical innovation at the component level does not necessarily have to result in a similar innovation at the system level (Level 2). It is, however, a necessary precondition. The (further) development of technology is motivated on the basis of the innovation environment, which is determined by market conditions for operators and provid- 
ers, energy and environmental policy measures etc. and is represented by Levels 3 and 4 in Figure 2.

The following reflections are mainly concerned with technologies used for the conversion of coal into electricity. Thus the analysis is carried out at a technology-based micro level (Level 2), which, from a technological point of view, however, exhibits a considerably high level of detail, since the technological system to be examined (i. e. the power plant process) is separated into components (Level 1) and analysed (Garcia and Calantone 2002). Against this background, an innovation is considered radical, if one or more newly developed components change the power plant system, which spurs the development of a new technological trajectory in power plant technology that differs considerably from existing technological trajectories and offers significant advantages (for example a leap in efficiency, lower emissions, lower costs etc.). An example is nuclear power plants, which were developed in the 1950s and 1960s and have been used commercially since the 1970s.

Figure 3 gives an overview of different technological trajectories. In this paper, an incremental change is defined as the further development of a technology while not leaving the chosen technological path. Thus, turbines in the field of power plants have been improved for decades, benefiting from innovations in other areas (for instance, powerful computers allowing for three-dimensional simulation) and thus finally creating an increase in efficiency. Another example is the development of materials that made it possible to increase steam parameters and thus contributed to an increase in efficiency of fossil fuel power plants.

Approaches in evolutionary economics accept that development paths are historically conditioned, which enables them to consider coincidences or path-dependence when analysing technological change. They are more focused on exploring transition and learning processes than balances. Their central element in terms of methodology are ex-post analyses in the form of case studies; the success of a certain technological trajectory is considered unpredictable. Actors have incomplete information, therefore technological development is inherently uncertain. These approaches are consequently sceptical about generalisable conclusions or predictions and instead generally tend to emphasise the context-dependence of innovation processes (Rennings 2000).

It is important to note that the terminology of variation and selection is, firstly, focused on technological innovations and, secondly, does not take into account complex feedback processes between variation and the selective environment. In the latter case one can speak about a process of co-evolution (Rennings 2000). Using the terminology of variation and selection, selective pressure of the environment may result in the establishment of a certain technologi- 
cal trajectory as the dominant technological paradigm. Economies of scale and scope, learning curves, positive cost-benefit ratios and compatibility with existing life styles, infrastructure and institutions create path-dependences and technological paradigms (Dosi 1988), i. e. lockin effects which impede the development of alternative options. The combustion engine or semiconductors are examples of such technological paradigms.

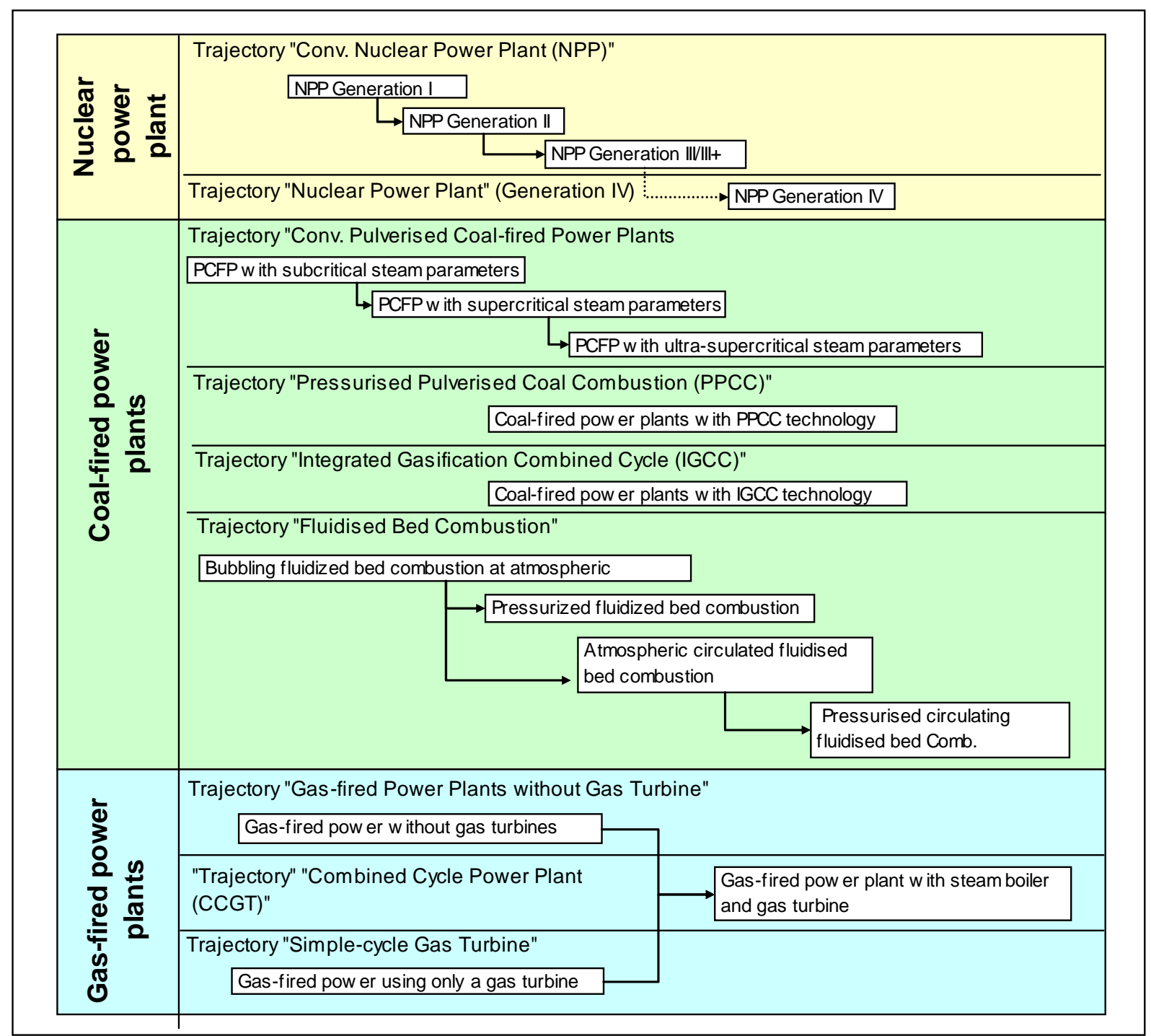

Figure 3: Key technological trajectories in power plant technology

In order that new technologies may be developed alongside such established paradigms, resistance has to be overcome. Policies pursuing this goal aim at opening ("unlocking”) a sociotechnical system (Faber and Frenken 2008). (Kemp 1997) mentions several determinants and success factors of technological change: new scientific findings (providing new technological opportunities), serious technological bottlenecks (e.g. the limits of additional emission reduc- 
tions based on additive technology, high costs of improving a technological trajectory, such as cost-intensive reductions in $\mathrm{CO}_{2}$ emissions, changes in demand, scarcity of resources or industrial conflicts), entrepreneurial activities and institutional support for radical new technologies.

Key success factors for a change in technology are the early establishment of market niches and the use of existing knowledge and technology, i.e. a certain compatibility with existing know-how, experiential knowledge and existing infrastructure. On the basis of these success factors, (Kemp 2007) (see also (Kemp and Rotmanns 2005)) suggests supporting a change for more eco-friendly technologies through a policy of transition management. In the Netherlands, the approach of transition management has been met with noticeable response from policy-makers in recent years. This strategy is based on the attempt to induce system innovations facilitating sustainable development. The goals of such innovations are technical, sociocultural, regulatory and economic systems which meet certain social requirements, such as the need for energy, housing, mobility or food.

System innovations are fundamentally different technologies for meeting these needs; they also necessitate addressing the economic, legal and socio-cultural conditions which determine the relevant technology (Rennings, et al. 2004). Examples of system innovations are the transitions from sailing ships to steamships or from coal-based to gas-based energy supply etc. System innovations, and thus the approach of transition management, are long-term transitions (at least 25 years). Based on the strong commitment of all participants to long-term goals they are to be achieved and implemented in concrete projects. The creation of protected spaces for up-and-coming, but not yet fully developed technologies is considered a promising strategy. This implies, for instance, the creation of temporary pilot markets, protected by funding programmes, subsidies or other regulatory measures.

According to (Berkhout, et al. 2004), however, such transitions from one technological regime to the next are not imperative. They list a range of other options, including, for instance, a re-orientation of the existing technological trajectories. Such a re-orientation implies that the existing system reacts to the selective pressure of its environment by improving innovations on the existing technological path (Berkhout 2005). Continuous improvements of an "old” technology before or after the introduction of a "new" technology, not least due to the new competitive situation, are familiar phenomena in innovation studies (Rosenberg 1972), and also for environmental innovations (Lutz, et al. 2005). Before a lock in situation can be overcome, a window of opportunity should be open (Sartorius and Zundel 2005). 


\section{Incremental and radical innovations in power plant - technology in Germany}

In the following, an ex-post analysis is used to examine the German R\&D portfolio for the field of large-scale power generation with a focus on the development of radical and incremental innovations. A particular focus is on research activities that were publicly funded during the last decades. Concomitantly, the R\&D portfolio examined represents a part of the industrial $R \& D$ portfolio, since a wide range of projects were cooperatively funded by public sponsors and the industry. Unlike purely industrial research, the public portfolio contains a large number of technologies and technological trajectories, which imply a much greater development risk. Thus the participation of the industry may also be interpreted in terms of a distribution of risks.

In a first step, the course of development is scrutinised and an analysis investigates incremental or radical innovations which received particular attention from research and development and examines whether and/or to what extent they established themselves in the market. The example of Pressurised Pulverised Coal Combustion (PPCC), which was considered a promising technology for the conversion of coal into electricity due to its large potential to increase efficiency, demonstrates that in spite of assumed advantages, radical innovations are not necessarily successful.

\subsection{The R\&D portfolio}

Table 1 depicts the development of the R\&D portfolio in the field of power plant technology in Germany over several decades. It differentiates between R\&D portfolio, power plant construction/demonstration and pilot plants and existing power plants. When interpreting this table, it should be noted that, for political reasons, research focused on different issues in each decade: in the 1970s, oil crises caused the research portfolio to focus on resource conservation and a change in energy sources, whereas in the 1980s environmental protection and in the 1990s climate protection was the guiding theme. Until 1998, the electricity market was a monopolised market. In this context, a wide range of pilot and demonstration plants were realised. Since 1998, however, a clear decrease in demonstration plants and a trend towards smaller and less cost-intensive technologies can be observed. The reasons are obvious: in a monopolised market, risks could simply be passed on to the end customer, whereas this is not possible in the now deregulated market.

To establish itself successfully, a technology passes through both the phases "R\&D portfolio" 
and "power plant construction/demonstration and pilot plants" and finally becomes a significant element of existing power plants. An example of particularly successful R\&D activities is the work done in the area of desulphurisation and denitrification, which became a major basis for implementing the German Großfeuerungsanlagenverordnung (GFAVO, Order on Large Combustion Plants): within one decade they passed through the R\&D phase and the demonstration phase, so that all existing German power plants could be provided with largescale systems by the early 1980s.

Table 1: National R\&D portfolio (selection of relevant technologies) and power plant development in the Federal Republic of Germany

\begin{tabular}{|c|c|c|c|}
\hline & National R\&D portfolio & $\begin{array}{c}\text { Power plant construc- } \\
\text { tion/demonstration and pilot } \\
\text { plants }\end{array}$ & Existing power plants \\
\hline $1970 \mathrm{~s}$ & $\begin{array}{l}\text { Coal gasification } \\
\text { Breeder reactor, Pressurized water } \\
\text { reactor (PWR), Boiling water reactor } \\
\text { (BWR), High Temperature Reactor } \\
\text { (HTR) } \\
\text { CHP and district heating } \\
\text { Improved efficiency of conventional } \\
\text { power plant technologies } \\
\text { Denitrification and desulphurisation } \\
\text { processes }\end{array}$ & $\begin{array}{l}\text { KDV Lünen (prototype plant) } \\
\text { AVR reactor (prototype } \\
\text { plant) } \\
\text { BWR, PWR } \\
\text { Conventional oil-, gas- and } \\
\text { coal-fired power plants } \\
\text { Partial desulphurisation } \\
\text { Coal-fired power plant in } \\
\text { Wilhelmshaven }\end{array}$ & $\begin{array}{l}\text { BWR, } \boldsymbol{P W R} \\
\text { Gas turbine plants } \\
\text { Conventional oil-, gas- and } \\
\text { coal-fired steam power plants } \\
\text { Hydroelectric power plants }\end{array}$ \\
\hline $1980 \mathrm{~s}$ & $\begin{array}{l}\text { Coal gasification } \\
\text { Combined-cycle power plants (gas } \\
\text { turbines, coal) } \\
\text { Steam power plants with intermediate } \\
\text { superheating } \\
\text { (Improved efficiency of conventional } \\
\text { power plant technologies) } \\
\text { Fluidised-bed combustion (FBC) } \\
\text { Denitrification, desulphurisation } \\
\text { Fusion }\end{array}$ & $\begin{array}{l}\text { Thorium high-temperature } \\
\text { nuclear reactor (THTR) } \\
\text { (demonstration plant) } \\
\text { Breeder reactor Kalkar } \\
\text { (demo plant) } \\
\text { Combined-cycle power plant } \\
\text { Gerstein (demo plant) } \\
\text { Völklingen (stat. FBC) } \\
\text { Coal gasification (Berrenrath) } \\
\text { PWR (Konvoi plant) } \\
\text { Coal-fired steam power plants } \\
\text { Windpower (Growian) } \\
\end{array}$ & $\begin{array}{l}\text { BWR, } P W R \\
\text { Conventional oil-, gas- and } \\
\text { coal-fired steam power plants } \\
\text { Hydroelectric power plants }\end{array}$ \\
\hline $1990 \mathrm{~s}$ & $\begin{array}{l}\text { Coal gasification (Kobra) } \\
\text { Pressurised pulverised coal combus- } \\
\text { tion (PPCC) } \\
\text { Fluidised-bed combustion (FBC) } \\
\text { Improved efficiency of conventional } \\
\text { power plant technologies (steam power } \\
\text { plants, gas turbines) } \\
\text { Wind power (onshore) } \\
\text { Biomass, photovoltaics, geothermal } \\
\text { power } \\
\text { Fuel cell technology } \\
\text { Fusion }\end{array}$ & $\begin{array}{l}\text { PFBC Cottbus (demo plant) } \\
\text { Conventional lignite-fired } \\
\text { power plants } \\
\text { combined-cycle gas turbine } \\
\text { (CCGT) power plants } \\
\text { Fuel cell projects } \\
\text { Geothermal power projects }\end{array}$ & $\begin{array}{l}\text { BWR, PWR } \\
\text { Conventional coal-fired power } \\
\text { plants using denitrification } \\
\text { and desulphurisation } \\
\text { Gas turbines } \\
\text { CCGT power plants } \\
\text { Hydroelectric power plants } \\
\text { Wind turbines }\end{array}$ \\
\hline $\begin{array}{l}\text { Since } \\
2000\end{array}$ & $\begin{array}{l}\text { Improved efficiency of conventional } \\
\text { power plant technologies } \\
\text { Carbon dioxide capture } \\
\text { Fluidised-bed combustion } \\
\text { Pressurised pulverised coal combus- } \\
\text { tion (terminated in 2005) } \\
\text { Fuel cell technology } \\
\text { Wind power (offshore) } \\
\text { Geothermal power, photovoltaics } \\
\text { Fusion }\end{array}$ & $\begin{array}{l}\text { CCGT power plants } \\
\text { BoA power plant (lignite-fired } \\
\text { power plant with optimised } \\
\text { plant design) } \\
\text { Wind turbines } \\
\text { Biomass power plants } \\
\text { Fuel cell projects } \\
\text { Geothermal power projects } \\
\text { Combined-cycle power plant } \\
\text { (topping turbine) }\end{array}$ & $\begin{array}{l}\text { BWR, PWR } \\
\text { Conventional coal-fired power } \\
\text { plants using denitrification } \\
\text { and desulphurisation } \\
\text { CCGT power plants } \\
\text { Hydroelectric power plants } \\
\text { Wind turbines } \\
\text { Biomass power plants }\end{array}$ \\
\hline
\end{tabular}

Bold print: radical innovations, italics: incremental innovations

Another successful example of the establishment of a radical system-level innovation in the market is the construction of nuclear power plants (pressurised-water and boiling-water reac- 
tors).

In the field of fossil fuel power plants, many technologies could not establish themselves beyond the phase of demonstration and pilot plants. It must be noted that no radical innovation has succeeded at the system level during the last three decades. This applies, for instance, to technologies for the conversion of coal into electricity on the basis of coal gasification, which did not succeed on an international scale either. Thus no fundamental change of path (change in technological trajectory) could be observed in the field of fossil fuel power systems during the last decades, despite the existence of new power plant models (e.g. Integrated Gasification Combined Cycles or Pressurised Pulverised Coal Combustion), which constitute radical innovations and stand out due to their higher degree of efficiency or eco-friendliness compared to established technologies.

At the component-level, however, a few changes in technological trajectories could be observed. One example in the field of coal-fired power plants is the transition from slag-tap firing to pulverised fuel firing with dry ash removal, which was triggered by the introduction of the German GFAVO (Order on Large Combustion Plants) prescribing strict limit values for nitrogen oxide. Another reaction to the prescription of emission limits is the development of scrubbing technologies to remove sulphur and nitrogen oxide from flue gases, which did not exist before and thus must be considered a radical innovation at the component level. The component-level changes mentioned did, however, not fundamentally change the actual power plant process as a whole and thus cannot be considered radical innovations at the system level "power plant“ (Level 2).

Other procedures, which are de facto alternatives to the above-mentioned $\mathrm{SO}_{2}$ and $\mathrm{NO}_{\mathrm{x}}$ scrubbing technologies, such as fluidised-bed combustion systems, could not establish themselves as expected, since their potential use entails also new restrictions (e.g. lower performance) and a dramatic change in the actual power plant process (e.g. replacement or fundamental modification of the steam generator). Fluidised-bed combustion systems offer the advantage of being compatible with a broad range of fuels and therefore serve a niche market today. Apart from few exceptions, the further development of fossil fuel power plant technology has had an incremental character. Thus, the increase in efficiency of conventional power plant technology by way of increasing the steam parameters pressure and temperature played a decisive role in all decades and independently of the demands and conditions created by energyand environmental policy. Due to this development a combination of established gas and steam cycles (CCGT plants) became possible which significantly increased degrees of efficiency. 
In the following, Pressurised Pulverised Coal Combustion is used as an example in order to examine why technologies that are considered radical innovations and are assumed to offer considerable advantages compared to conventional technologies could nevertheless not establish themselves.

\subsection{Pressurised Pulverised Coal Combustion (PPCC) as a radical innovation}

An increase in efficiency is often the main motivation for conducting $R \& D$ projects. Based on the state of the art at the beginning of an R\&D project, the efficiency potentials indicated - in comparison to established competitive technology - are generally seen from a medium- or long-term perspective. In contrast to conventional coal-fired power plants, Pressurised Pulverised Coal Combustion is a combined process, in which a gas turbine receives direct pressure using pressurised flue gas from a coal firing. Unlike conventional processes, PPCC requires hot-gas filtration at highest temperatures (approx. $1400^{\circ} \mathrm{C}$ ), which at the beginning of $\mathrm{R} \& \mathrm{D}$ activities implied venturing into uncharted territory. In addition, the boiler design had to be modified for operation under pressure. After 1985, only dry pulverised fuel firing was used in power plants due to emission limits. Realising the PPCC process would have required slag-tap firing, thus implying a trend reversal. In summary, the new model, requiring the development of completely new components (such as hot-gas cleaning) and the modification of established components (such as the steam generator), qualified the PPCC process as a radical innovation in the field of power plants.

Research and development activities were started in the late 1980s in the context of a cooperative research project, which included many private companies (operators and constructors). In 2003, however, R\&D activities were terminated and the promising power plant process, which accounted for development cost of approximately €90m, was never realised.

Table 2 contains information on the efficiency of state-of-the-art technology in the late 1980s as well as efficiency projections for several power plant technologies at that time. The significant advantages of Pressurised Pulverised Coal Combustion are clearly visible. Compared to conventional power plant technology, PPCC promised an increase in efficiency by 5 to 10 percentage points, which was the actual motivation for the industry and public sponsors to participate in the project. A comparison with today's state of the art, however, paints a different picture. It becomes clear that the potential of conventional power plant technology to increase its efficiency had been greatly underestimated. The assumed efficiency advantage of PPCC thus diminished considerably over time. Experts had not expected the remarkable pro- 
gress that took place in material research and in computer simulation, which particularly benefitted conventional technology. A comparison of today's efficiency projections, which are also listed in Table 2, shows that PPCC has now only an efficiency advantage of 2 percentage points. Since conventional and proven technology achieves similar degrees of efficiency and high technological availability is ensured, work in the field of PPCC was terminated after 15 years of continuous R\&D activities. The core problem of PPCC, high temperature ash removal, was solved at the stage of experimental plants. The next step would have been constructing a pilot plant and afterwards a demonstration plant. This was, however, not supported by public sponsors, neither by the industry, which sponsored all project phases but whose participation decreased throughout the project.

A similar picture may be painted in the case of power plants based on Integrated Gasification Combined Cycle (IGCC). Several of such large-scale plants currently operate, for example in the Netherlands (Buggenum), Spain (Puertollano) and in the USA. Since the technological availability necessary to be competitive cannot be provided with those plants, their operation is subject to high risk. This risk has a direct impact on profitability, thus global power plant operators do not include them in their plant portfolio. The few plants that were built currently serve niche markets (such as refineries).

Table 2: Net efficiency (state of the art and projections) at the beginning and at the end of R\&D activities in the field of PPCC for different trajectories of power plant technology

\begin{tabular}{|c|c|c|c|c|}
\hline & \multicolumn{2}{|c|}{1989} & \multicolumn{2}{|c|}{2003} \\
\hline & State of the Art & \begin{tabular}{|c|} 
Projections $1989-$ \\
2020
\end{tabular} & State of the art ${ }^{2)}$ & $\begin{array}{c}\text { Projections }^{2), 4)} \\
2003-2020\end{array}$ \\
\hline CCGT (natural gas) & $52 \%^{1)}$ & $54 \%{ }^{7) 8)}$ & $58 \%$ & $65 \%$ \\
\hline $\begin{array}{l}\text { Conventional coal- } \\
\text { fired power plants } \\
\text { (brown coal) }\end{array}$ & $36 \%^{1)}$ & n.s. & $43,5 \%$ & $50 \%$ \\
\hline $\begin{array}{l}\text { Conventional coal- } \\
\text { fired power plants } \\
\text { (hard coal) }\end{array}$ & $40 \%^{1)}$ & $44 \%{ }^{6)}$ & $46,9 \%$ & $53 \%$ \\
\hline IGCC (brown coal) & - & $49 \%^{1), 3)}$ & & \\
\hline IGCC (hard coal) & - & $45-47 \%^{1), 3)}$ & $45-48 \%$ & $54-57 \%$ \\
\hline PFBC & - & $44 \%^{1), 3)}$ & - & $53-55 \%^{5)}$ \\
\hline PPCC & - & $49-53 \%^{1), 3)}$ & - & $53-55 \%$ \\
\hline \multicolumn{5}{|c|}{$\begin{array}{l}\text { Note: 1) (Pruschek, et al. 1990) 2) (COORETEC 2003) 3) Turbine inlet temperature: } 1150^{\circ} \mathrm{C} \text { 4) Specifications for } 2020 \\
\text { 5) "Second" generation 6) (Lezuo, et al. 1989) 7) (Martin 1988) 8) Turbine inlet temperature: } 1300^{\circ} \mathrm{C} \\
\text { Abbreviations: CCGT: Combined Cycle Gas Turbine, IGCC: Integrated Gasification Combined Cycle, PFBC: Pressurised } \\
\text { Fluidised-Bed Combustion, PPCC: Pressurised Pulverised Coal Combustion }\end{array}$} \\
\hline
\end{tabular}




\subsection{Supercritical coal-fired power plants as an incremental innovation}

The results outlined above also hold true for incremental change in technology, such as the transition to supercritical steam parameters. The development towards high steam temperatures and steam pressures directly resulted in improved efficiency and took many decades, as shown in Figure 4.

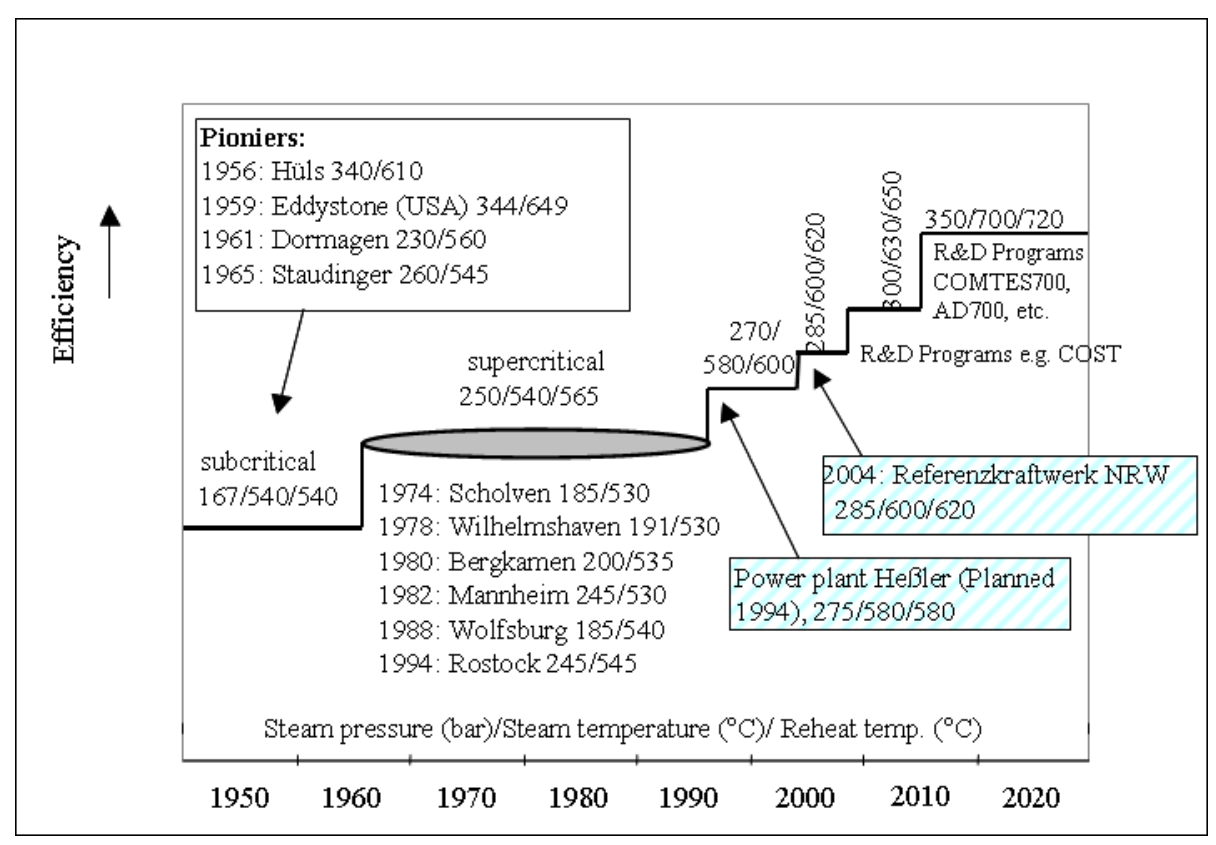

Figure 4: $\quad$ Development of steam parameters in hard-coal-fired power plants

The individual plants shown in the figure represent milestones in the development of steam parameters. Supercritical steam parameters had been realised in some power plants ("pioneers") since the late 1950s, they were, however, marketable only 30-40 years later. On the one hand, this was due to the use of expensive austenitic steels. On the other hand, the materials used in the pioneer plants were there found to have inadequate thermal properties, which significantly decreased technological availability. Only with increasing progress in the field of material research was it possible to develop materials which met thermal requirements and were more cost-efficient. While for hard-coal-fired power plants the transition to supercritical steam parameters took place in the 1980s, for lignite-fired power plants it was induced in the 1990s. Consequently, all newly constructed lignite-fired power plants in Germany operate with supercritical steam parameters, which, along with other methods, increase net efficiency to as much as $42 \%$. Currently, intensive research is conducted in order to further increase live-steam parameters (350 bar, $700^{\circ} \mathrm{C}$ ). Ultra-supercritical hard-coal-fired power plants are 
predicted to achieve an efficiency of more than $50 \%$ (see Table 2). The efficiency advantage of competitive new trajectories of power plant technology thus continuously decreases. Apart from an increase in efficiency by increasing temperature and pressure, other improvements must be noted. For example, the design of gas and steam turbines and their components was optimised using three-dimensional simulations, which were made possible by the introduction of more powerful computers. The same holds true for the design of other components (e.g. cooling tower) and the optimisation of the whole power plant process. These individual developments accumulated to a considerable increase in efficiency of established trajectories of power plant technology (COORETEC 2003).

\section{Carbon dioxide capture in power plants: radical or in- cremental?}

In the context of a reduction in $\mathrm{CO}_{2}$ emissions from fossil fuel power plants, the use of $\mathrm{CO}_{2}$ capture and storage (CCS) technologies is increasingly debated (IEA 2008a, IPCC 2005). However, in the economic debate, CCS is often seen as a single technology and the introduction only depends on the level of carbon prices (Otto and Reilly 2008). $\mathrm{CO}_{2}$ abatement costs are estimated between 35 and 50 Euro for 2020 (SRU - Sachverständigenrat für Umweltfragen 2008). For many experts, CCS may only be seen as an incremental innovation since it is based on fossil fuels. In fact, there are considerable differences between the technologies in question. Three technological processes are currently favoured: in post-combustion, $\mathrm{CO}_{2}$ is removed from flue gases by means of solvents and thus captured after combustion. In oxy-fuel combustion, coal is not burnt using the ambient air but with pure oxygen and recycled flue gas, consisting mainly of $\mathrm{CO}_{2}$ and water vapour. The flue gas produced consists mainly of $\mathrm{CO}_{2}$. In the third process, pre-combustion, carbon is removed from the energy carrier prior to the actual combustion process in the power plant. This procedure is used in Integrated Gasification Combined Cycle (IGCC) power plants. The three technological trajectories differ in their technological proximity to existing power plant models, in their marketability, in the risks associated with their use and their expected financial advantages in comparison with known technologies. In principle, power plants using $\mathrm{CO}_{2}$ capture combine a trajectory of power plant technology with a capture procedure. Thus the following comparative assessment, as shown in Table 3, differentiates between the actual basic process and the capture procedure. Subsequently, the overall process is assessed. 
A risk assessment for $\mathrm{CO}_{2}$ transport and storage is not required in the following analysis, since it has no influence on the comparison of technological trajectories.

Table 3: Assessment of technological trajectories of $\mathrm{CO}_{2}$ capture

\begin{tabular}{|c|c|c|c|}
\hline & Post-combustion & Oxy-fuel & Pre-combustion \\
\hline \multicolumn{4}{|c|}{ Assessment of the basic process } \\
\hline Basic process & $\begin{array}{l}\text { Super- or ultra- } \\
\text { supercritical power } \\
\text { plant }\end{array}$ & $\begin{array}{l}\text { Super- or ultra- } \\
\text { supercritical power } \\
\text { plant }\end{array}$ & $\begin{array}{l}\text { Integrated Gasification } \\
\text { Combined Cycle (IGCC) }\end{array}$ \\
\hline Characterisation & $\begin{array}{l}\text { Incremental innovation } \\
\text { (Level 2) }\end{array}$ & $\begin{array}{l}\text { Incremental innovation } \\
\text { (Level 2) }\end{array}$ & $\begin{array}{l}\text { Radical innovation } \\
\text { (Level 2) }\end{array}$ \\
\hline Commercially available? & Yes & Yes & Yes \\
\hline In use today? & Yes & Yes & (No), Niches \\
\hline $\begin{array}{l}\text { Drastic modification of the } \\
\text { basic process required due to } \\
\text { CSS? }\end{array}$ & No & $\begin{array}{l}\text { Yes (steam generator, } \\
\text { firing) }\end{array}$ & No \\
\hline \multicolumn{4}{|c|}{ Assessment of CCS technology } \\
\hline CCS process & $\begin{array}{l}\text { Chemical solvent } \\
\text { scrubbing }\end{array}$ & Air separation unit & $\begin{array}{l}\text { Physical solvent scrub- } \\
\text { bing }\end{array}$ \\
\hline Characterisation & $\begin{array}{l}\text { Incremental innovation } \\
\text { (Level 2) }\end{array}$ & $\begin{array}{l}\text { Incremental innovation } \\
\text { (Level 2) }\end{array}$ & $\begin{array}{l}\text { Incremental innovation } \\
\text { (Level 2) }\end{array}$ \\
\hline Commercially available? & Yes (chem. industry) & Yes (chem. industry) & Yes (chem. industry) \\
\hline $\begin{array}{l}\text { Combination with basic } \\
\text { process possible? }\end{array}$ & $\begin{array}{l}\text { Yes } \\
\text { (but scale up) }\end{array}$ & $\begin{array}{l}\text { Yes } \\
\text { (but scale up) }\end{array}$ & $\begin{array}{l}\text { Yes } \\
\text { (but scale up) }\end{array}$ \\
\hline \multicolumn{4}{|c|}{ Assessment of overall process } \\
\hline $\begin{array}{l}\text { Efficiency loss compared to } \\
\text { basic process }\end{array}$ & High & Medium & Medium \\
\hline $\begin{array}{l}\text { Technological development } \\
\text { potential }\end{array}$ & $\begin{array}{l}\text { High } \\
\text { (new solvents) }\end{array}$ & Medium & $\begin{array}{l}\text { Very high } \\
\text { (new solvents, high effi- } \\
\text { ciency potential of the } \\
\text { basic process) }\end{array}$ \\
\hline Specific characteristics & $\begin{array}{l}\text { Retrofitting of existing } \\
\text { power plants possible }\end{array}$ & $\begin{array}{l}\text { More environmentally } \\
\text { friendly }\end{array}$ & $\begin{array}{l}\text { Polygeneration of several } \\
\text { products (electricity, } \mathrm{H}_{2} \\
\text { etc.) } \\
\text { High investment cost of } \\
\text { the basic process }\end{array}$ \\
\hline Risk & Medium & Medium to high & High \\
\hline
\end{tabular}

A comparison of basic processes makes clear that post-combustion as well as oxy-fuel combustion are added to power plant processes which dominate the global market for power plant technology. They confirm the impression that this kind of CCS technology is only an incremental improvement of coal power plants. The IGCC power plant, on the other hand, is considered a radical innovation, which is, in principle, commercially available, but is hardly used in power generation. Large-scale use requires further optimisation and improvement of components (gasifier, gas turbine) to achieve the necessary degree of availability. 
When combining basic processes with capture processes, a possible modification of the basic power plant process may be considered. With post-combustion and pre-combustion, however, modifying the basic process is generally not necessary. From a technological as well as an economic point of view, the steam generator and the firing are the decisive components in a power plant process. In oxy-fuel combustion, they need to be newly dimensioned and designed, thus considerably increasing the technological risk compared to both abovementioned processes.

Components of different CCS technologies are commercially available and are currently used in chemical industry. The air separation unit required for oxy-fuel combustion, for instance, is state of the art. $\mathrm{CO}_{2}$ scrubbing, which is based on the principle of chemical and physical absorption by means of solvents, is currently used in chemical industry (e.g. in ammonia production or refineries). Due to the high volume flow rates of a power plant, the technological components currently available need to be scaled up in all processes. The individual CCS processes do not differ in their technological risk.

Using $\mathrm{CO}_{2}$ capture processes results in substantial efficiency losses for all technological trajectories, caused by the additional use of energy for air separation (oxy-fuel combustion) and by the regeneration of the "rich" solvent containing the $\mathrm{CO}_{2}$ (post-combustion, precombustion). From today's perspective, efficiency losses are largest in the overall process of post-combustion, while they are more moderate in other processes. The development of improved solvents, however, is expected to unleash remarkable efficiency potentials. The highest efficiency potential is found in the overall process of pre-combustion, since it is particularly suited to $\mathrm{CO}_{2}$ scrubbing for reasons of technology and, moreover, its basic process is regarded as having high efficiency potential.

The individual technological trajectories exhibit several additional characteristics which may significantly influence their use. Post-combustion, for instance, is the only process suitable for retrofitting (the addition of new technology or features to existing plants). Against the backdrop of increasing efforts to mitigate greenhouse gas emissions, this characteristic may be considered an advantage. Oxy-fuel combustion is regarded as more eco-friendly, since no chemical additives are required. In pre-combustion, the hydrogen used for electricity generation may also be used for other purposes. This process may thus be used very flexibly and possibly pave the way for a hydrogen economy.

All technological trajectories are associated with significantly higher investments, exceeding those of the basic process by at least $50 \%$ (ignoring $\mathrm{CO}_{2}$ transport and storage). When comparing the necessary investments of the basic processes, those of steam power plants are, from 
today's perspective, clearly higher than those of an IGCC power plant.

Since CCS technologies do not differ in risk, the evaluation of the overall process is mainly determined by the basic process. Based on the results of the ex-post analysis, the risk of precombustion is considered the highest, as this process is added to a basic process constituting a radical innovation. Due to the modification of the steam generator, oxy-fuel combustion is thus considered to pose a somewhat higher risk than post-combustion, which has closest technological proximity to established power plant processes.

Figure 5 shows a comparison of different CCS technologies with regard to the associated risks and their expected advantages. Both post-combustion and oxy-fuel combustion pose relatively low risks to investors. The use of IGCC in combination with CCS, on the other hand, may involve more difficulties as regards continuous commercial operation. Yet such technologies may prove more profitable than others.

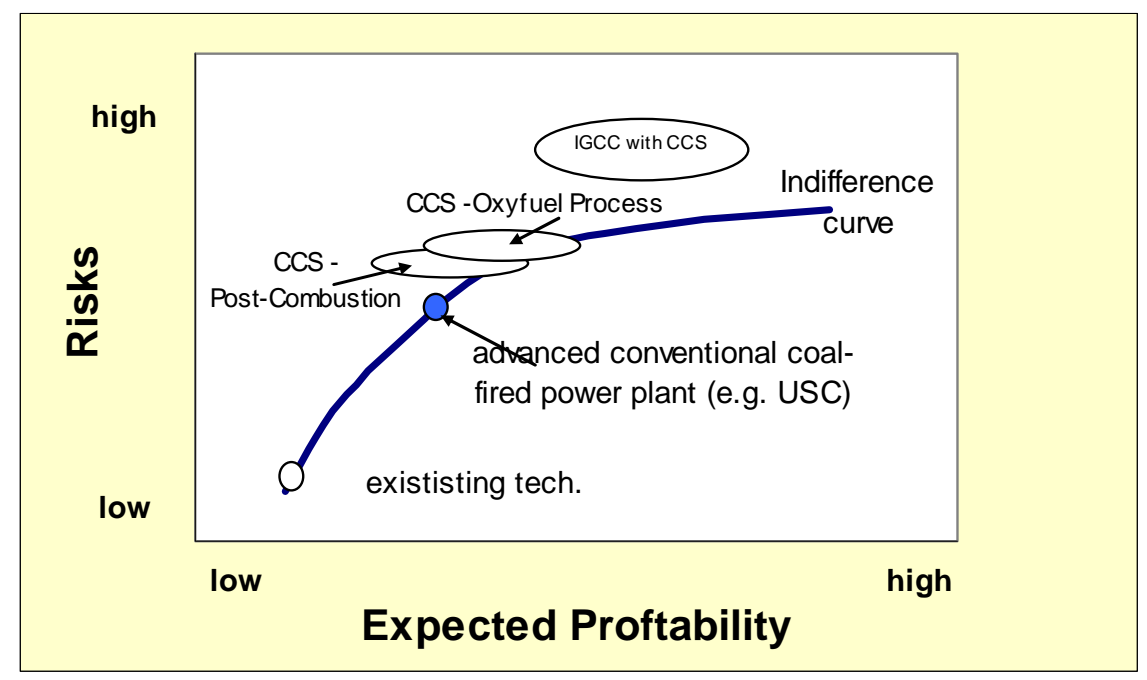

Note: Profitability of technologies depends, amongst other things, on expectations with regard to factor prices (e.g. development of $\mathrm{CO}_{2}$ permit prices). "Clouds" were used to classify the uncertainties for different technologies in the figure.

Figure 5: The risk/profitability ratio for CCS technologies

Since investors in the field of power plants are currently highly risk-averse, it must be anticipated that radical technologies are associated with higher risks than an incremental improvement. Thus their large-scale establishment is possible only if existing risks are significantly reduced or expected profitability can be significantly increased. 


\section{Conclusions}

In the case of power plant technology, one observes a classical lock-in situation - not to be equated, however, with the well-known case of the typewriter keyboard (the QWERTY example), where the less convenient system was successful in technological evolution due to advantages of standardisation (David 1985). Pressurised Pulverised Coal Combustion, on the other hand, did indeed perform less well in a dynamic comparison and did thus rightly not establish itself. Whereas it might have come out ahead in a comparison with the original reference technology, technological progress of the "old" technology was significantly underestimated.

The classical lock in situation is supported by the deregulation of the electricity market. Many hard-coal-fired power plants built in the 1970s and 1980s have to be regarded as unique and tailored to the specific needs of their operators. Increasing global demand for power plants, but also deregulation of the electricity market has changed the general conditions for European power plant constructors. The main goal is global competitiveness (Level 4).

This will probably not make enterprises more willing to take risks, since they are now exposed to serious competition which does not forgive wrong decisions. In a competitive market, more importance is attached to the criterion of profitability.

In this context, cooperative research - cooperation with competitors - becomes increasingly relevant. It ensures that development risks are pooled and may thus be understood as risk sharing in the broader sense. Furthermore, participation in cooperative research projects gives access to information, which might eventually constitute a competitive advantage. One example is the research project COMTES700 (development of ultra-supercritical power plants), in which besides research institutes a number of national and international utilities (e.g. E.ON, EdF etc.) and power plant constructors take part (Jäger 2005).

Power plant standardisation, elimination of redundancies and reduced construction time further contributed to reductions in investment costs and are expected to do so in the future. Power plant design strives to meet the needs of global (in particular, Asian) consumers. The call for increased plant availability plays a decisive role in this: it has to be guaranteed by constructors, who thus face high financial risks and are consequently less willing to take the risk of "experimenting" with new technology. New or improved technologies first have to be presented and tested in the country of manufacture before being exported. A successful example is the introduction of supercritical hard-coal-fired power plants in China. Whereas Europe had completely switched to supercritical power plants in the 1990s, in China only plants with 
subcritical steam parameters were constructed. Only since 2000, with a time lag of roughly 10 years, supercritical power plants have been constructed on a large-scale basis. It can be expected that CCS technology will be diffuse to China with similar delays, and perhaps only partial CCS will be realised in the near future which may be much more cost effective (MIT, 2008). However, due to the political pressures on emerging countries like China, and the abundance of coal reserves, CCS technologies are likely to be used in theses countries over the long run.

An ex-post analysis shows that - in contrast to incremental innovations - radical innovations mostly did not succeed, despite their evident advantages (more eco-friendly, more efficient). This holds particularly true in the field of power plant systems. When focusing on fossil fuel power plant technology, several radical component-level innovations were made and diffused into the market during the last three decades. Yet no radical innovations were made at the system level in this field, which indicates its strong path-dependence. The risk that new technological trajectories cannot establish themselves is particularly high in the case of newly developed components or a trend reversal at the component level which eventually constitute a radical innovation in the power plant system. In the field of fossil fuel power plant technology, an innovation is more likely to succeed the more it follows established technological trajectories.

The results gained in the ex-post analysis also allow for an assessment of power plant technologies for future use, as has been shown using the example of carbon capture technologies. The results are inherently uncertain, since it is not possible to precisely predict the general conditions prevailing when using the technology. Highest priority must be given to pathdependence, since it has been observed in the field of coal-fired power plants for decades and carries more weight than other criteria.

From a social perspective, a reasonable strategy would be to further develop all three CCS technologies. While the incremental post combustion technology has the advantage that it can be used for retrofitting (which may be most urgent e.g. for existing German power plants), the radical pre combustion technology is more efficient but the window of opportunity (at least in Germany) may be already closed when the technology is in a mature phase of development. Thus a reasonable R\&D portfolio should include both post and pre combustion technologies, at least for international appliances. If R\&D on CCS is left to energy suppliers, it can be expected that only the incremental technology is realised and that the radical technology will not be further developed.

The analyses conducted also indicate that the dynamics of technological progress and thus the 
development of incremental innovations have often been underestimated. Advantages ascribed to a radical innovation in comparison to incremental development have changed over time due to research and development activities. Consequently, technologies in the R\&D phase should be evaluated gradually, in time intervals, since every indication of, for instance, efficiency and cost potential has to be regarded as a mere snapshot.

In other words: New technologies have to compete with "old" technologies, while the latter are not to be considered static - it has to be taken into account that the old technology is, in the light of its competition with the new technology, continually further developed. This experience gained in innovation research was confirmed using the example of power plant technology. Thus, sceptical views regarding a transition from one technological regime to the next have been confirmed in our paper. There is a range of other options, one example is a possible re-orientation of existing technological trajectories (of conventional coal-fired power plants in this case). Such a re-orientation implies that the existing system reacts to the selective pressure of its environment by incrementally developing innovations on the existing technological path (in this case, in the form of supercritical coal-fired power plants). While planning any transition, such development paths should also be taken into account.

The development of new technologies in the field of power plants is essentially motivated by an envisaged increase in efficiency. This holds true independently of the conditions created by energy and environmental policy. Yet the ex-post analysis shows that this criterion is generally overestimated, whereas other characteristics (e.g. availability) which significantly influence economical power plant operation and thus profitability do not receive sufficient attention.

Deregulation of the electricity market constitutes a fundamental change in environment. It is evident that more pilot and demonstration plants were constructed before deregulation than afterwards, since in a monopolised market, potential cost of failure could more easily be passed on to the end customer. Consequently, there will probably be less willingness in the future to take the risk of developing and implementing a radical innovation at the system level.

\section{Acknowledgements}

The authors would like to express their appreciation for the support in the context of the project "Decision criteria towards efficiency of strategic R\&D subsidies - innovation-economic principles and applications to new energy technologies", which was funded by the support programme EDUARD (Energie-Daten und Analyse R\&D - Energy Data and Analysis R\&D) 
initiated by the German Federal Ministry of Economics and Technology (BMWi).

\section{References}

Berkhout, F., 2005. Technological Regimes, Environmental Performance and Innovation Systems: Tracing the Links., in: Weber, M. and J. Hemmelskamp (Eds.) Towards Environmental Innovation Systems. Berlin, Springer.

Berkhout, F., A. Smith and A. Stirling, 2004. Socio-technical regimes and Tranistion Contexts, in: Elzen, B., F. W. Geels and K. Green (Eds.) System Innovation and the Transition to Sustainability - Theory, Evidence and Policy. Cheltenham, Edward Elgar.

COORETEC, 2003. Forschungs- und Entwicklungskonzept für emissionsarme fossil befeuerte Kraftwerke, BMWA Dokumentation Nr. 527.

David, P. A., 1985. Clio and the Economics of QWERTY. American Economic Review of International Political Economy, 75, 332 - 337.

Dosi, G., 1988. Sources, Procedures, and Microeconomic Effects of Innovation. Journal of Economic Literature, 1988, 1120-1171.

Faber, A. and K. Frenken 2008. Models in evolutionary economics and environmental policy: Towards an evolutionary environmental economics. Technological Forecasting \& Social Change, doi: 10.1016/j.t4echnfore.2008.04.009.

Freemann, C., 1992. The Economics of Hope, London, New York.

Garcia, R. and R. Calantone, 2002. A critical look at technological innovation typology and innovationess terminology: a literature review. The Journal of Product Innovation Management, 2002, 110- 132.

Geels, F. W., 2004. Understanding System Innovations: a critical literature review and a conceptual synthesis, in: Elzen, B., Geels, F.W., Green K. (Ed.) System Innovation and the Transition to Sustainability - Theory, Evidence and Policy. Cheltenham, Edward Elgar.

Geels, F. W., B. Elzen and K. Green, 2004. General Introduction: system innovation and transitions to sustainability, in: Elzen, B., Geels, F.W., Green K. (Ed.) System Innovation and the Transition to Sustainability - Theory, Evidence and Policy. Cheltenham, Edward Elgar.

IEA, 2008a. CO2 Capture and Storage: A key carbon abatement option, Paris, OECD/IEA.

IEA, 2008b. World Energy Outlook, (IEA), I. E. A., Paris, IEA/OECD.

IPCC, 2005. IPCC Special Report on Carbon Dioxide Capture and Storage., Working Group III of the Intergovernmental Panel on Climate Change, New York, Cambridge University Press.

Jäger, G., 2005. Großversuch in Scholven. BWK, 57, 36-37.

Kemp, R., 1997. Environmental Policy and Technical Change, Cheltenham, Brookfield, Edward Elgar.

Kemp, R., 2007. An Example of "Managed Transition": The Transformation of the Waste Management Subsystem in the Netherlands (1960-2000), in: LehmannWaffenschmidt, M. (Ed.) Innovations Towards Sustainability - Conditions and Consequences. Heidelberg, Physica Verlag.

Kemp, R. and A. Arundel, 1998. Survey Indicators for Environmental Innovation, IDEA, Indicators and Data for European Analysis) paper series 8/1998.

Kemp, R. and J. Rotmanns, 2005. The Management of the Co-Evolution of Technical, Environmental and Social Systems, in: Weber, M. and J. Hemmelskamp (Eds.) Towards Environmental Innovation Systems. Berlin, Springer-Verlag. 
Klemmer, P., U. Lehr and K. Löbbe, 1999. Umweltinnovationen: Anreize und Hemmnisse, Berlin.

Lezuo, A., K. Riedle and E. Wittchow, 1989. Entwicklungstendenzen steinkohlebefeuerter Kraftwerke. BWK, 41, 13-21.

Lutz, C., B. Meyer, C. Nathani and J. Schleich, 2005. Endogenous technological change and emissions: the case of the German steel industry Energy Policy, 33, 1143-1154.

Martin, H., 1988. Steigerung des prozesswirkungsgrades kohlegefeuerter Kraftwerke. VGB Kraftwerkstechnik, 68, 219-225.

OECD, 2005. Guidelines for Collecting and Interpreting Technological Innovation Data - Oslo Manual, The Measurement of Scientific and Technical Activities Series, Paris.

Otto, V. M. and J. Reilly, 2008. Directed technical change and the adoption of CO2 abatement technology: The case of $\mathrm{CO} 2$ capture and storage. Energy Economics, 30, 2879-2898

Pruschek, R., U. Renz and E. Weber, 1990. Kohlekraftwerke der Zukunft. Stand und Entwicklung, Erprobung und Planung neuer Kohlekraftwerks-Technologien, Studie im Auftrag des Ministers für Wirtschaft, Mittelstand und Technologie des Landes NRW, Düsseldorf.

Rennings, K., 2000. Redefining Innovation - Eco-Innovation Research and the Contribution from Ecological Economics. Ecological Economics, 2000, 319 - 332.

Rennings, K., R. Kemp, M. Bartolomeo, J. Hemmelskamp and D. Hitchens, 2004. Blueprints for an Integration of Science, Technology and Environmental Policy, Mannheim, ZEW.

Rennings, K. and T. Zwick, 2002. The Employment Impact of Cleaner Production on the Firm Level - Empirical evidence from a Survey in Five European Countries. International Journal of Innovation Management (IJIM), Special Issue on „The Management of Innovation for Environmental Sustainability“, 6, 319 342.

Rosenberg, N., 1972. Factors Affecting the Diffusion of Technology. Explorations in Economic History, 10, 3-33.

Sartorius, C. and S. Zundel (Eds.), 2005. Time Strategies, Innovation and Environmental Policy, Cheltenham.

SRU - Sachverständigenrat für Umweltfragen, 2008. Umweltschutz im Zeichen des des Klimawandels, Berlin.

Vellinga, P., 2004. Foreword, in: Elzen, B., F. W. Geels and G. K. (Eds.) System Innovation and the Transition to Sustainability - Theory, Evidence and Policy. Cheltenham, Edward Elgar. 